\title{
ANALISIS RESPON PENAWARAN PADI INDONESIA
}

\section{ANALYSIS OF SUPPLY RESPONSE OF INDONESIAN PADDY}

\author{
Anang Sulistyo ${ }^{1)}$, Syafrial $^{2)}$, Ratya Anindita ${ }^{2)}$ \\ 1)Mahasiswa Program Pascasarjana Fakultas Pertanian Universitas Brawijaya \\ ${ }^{2)}$ Dosen Jurusan Sosial Ekonomi Fakultas Pertanian Universitas Brawijaya
}

\begin{abstract}
ABSTRAK
Beras merupakan bahan pangan bagi sebagian besar penduduk Indonesia. Penawaran beras di Indonesia terdiri dari produksi dalam negeri dan impor dari negara lain. Ketergantungan terhadap beras impor dari tahun ke tahun cukup tinggi, yaitu 500 ribu sampai 2 juta ton per tahun.Peningkatan produksi padi merupakan upaya untuk memenuhi kebutuhan masyarakat dan mengurangi impor. Penelitian ini bertujuan untuk (1) Menganalisis perkembangan penawaran padi Indonesia, (2) Menganalisis faktor-faktor yang mempengaruhi luas areal panen padi Indonesia, (3) Menganalisis faktor-faktor yang mempengaruhiproduktivitas padiIndonesia dan Menganalisisrespon (elastisitas) penawaran padi Indonesia dalam jangka pendek dan jangka panjang.Metode analisis yang digunakan yaitu dengan pendekatan model respon penawaran Nerlove. Hasil analisis menunjukkan bahwa elastisitas penawaran padi Indonesia dalam jangka pendek sebesar 0,088 dan elastisitas jangka panjang sebesar 0,153. Hal ini menunjukkan bahwa petani padi respon terhadap perubahan harga. Nilai elastisitas ini berada pada kisaran inelastis, artinya presentase perubahan penawaran lebih kecil daripada harganya yaitu sebesar 0,088 persen dalam jangka pendek dan 0,153 persen dalam jangka panjang sebagai akibat perubahan 1 persen harga gabah.
\end{abstract}

Kata kunci: beras, impor, produksi, elastisitas

\begin{abstract}
ABSTACT
Rice is the food for the majority of Indonesian population. Indoensian rice supply consists of domestic production and imports from other countries. Dependence on imported rice from year to year is high, ie 500 thousand to 2 million tons per year. Increasing rice production is an effort to meet the needs of the community and reduce imports. This study aims to (1) Analyze the development of rice supply in Indonesia, (2) Analyze the factors affecting the area of Indonesia's rice harvest, (3) Analyze the factors affecting Indonesian rice productivity and (4) Analyze the response (elasticity) of rice supply Indonesia in the short and long term. The analytical methodwas the response model approach Nerlove deals. The analysis showed that Indonesia's rice supply elasticity in short term was 0.088 and in long-term was 0.153. This indicateds that rice farmers were response on price changes. This elasticity value was in inelastic range meaning that the percentage change of spply was smaller than price that was equal to 0.088 per cent in the short term and 0,153 per cent in the long term as a result of 1 percent change in the price of paddy.
\end{abstract}

Keywords: rice, import, production, elasticity 


\section{PENDAHULUAN}

Beras merupakan bahan pangan pokok bagi sebagian besar penduduk Indonesia. Hal yang cukup menarik adalah di beberapa daerah yang dahulu makanan pokoknya berasal dari pangan lokal seperti sagu yang banyak dikonsumsi oleh masyarakat di Maluku dan Papua, serta jagung dikonsumsi oleh masyarakat di NTT telah bergeser ke pangan nasional yaitu beras (Ariani 2010). Tingkat partisipasi konsumsi beras di berbagai wilayah yang lain pun cukup tinggi, yaitu rata-rata hampir mencapai 100 persen, yang berarti hampir semua rumah tangga telah mengkonsumsi beras. Kecenderungan tersebut tidak hanya terjadi pada rumah tangga perkotaan tetapi juga rumah tangga di pedesaan, walaupun umumnya tingkat partisipasi di desa masih lebih rendah daripada di kota. Bila dilihat antar pulau, maka tingkat partisipasi konsumsi beras tidak jauh berbeda antara pulau yang satu dengan pulau yang lain, yaitu hampir 100 persen (Hanani, 2010).

Menurut Suryana et. al. (2001), sebagian besar penduduk Indonesia menghendaki adanya pasokan (penyediaan) dan harga beras yang stabil, tersedia sepanjang waktu, terdistribusi secara merata dan dengan harga yang terjangkau. Selama ini, penyediaan kebutuhan beras dilakukan dengan dua cara yaitu memproduksi sendiri di dalam negeri dengan memanfaatkan sumber daya

dan teknologi yang ada dan dengan mengimpor dari negara lain. Pemerintah Indonesia berusaha untuk memenuhi kebutuhan beras dari produksi domestik dengan menjadikan swasembada beras sebagai kebijakan nasional.

Permasalahan utama dalam mewujudkan swasembada beras di Indonesia saat ini adalah pertumbuhan permintaan pangan yang lebih cepat dari pertumbuhan penyediaannya. Permintaan yang meningkat cepat tersebut merupakan resultante dari peningkatan jumlah penduduk, pertumbuhan ekonomi, peningkatan daya beli masyarakat dan perubahan selera. Sementara itu kapasitas produksi pangan nasional pertumbuhannya lambat bahkan stagnan karena kompetisi dalam penggunaan sumberdaya lahan dan air serta stagnannya pertumbuhan produktivitas lahan dan tenaga kerja pertanian.

Kedepan masalah peningkatan produksi padiakan semakin kompleks yang dicirikan dengan menyusutnya lahan baku tanaman pangan akibat konversi lahan, semakin terbatasnya anggaran pemerintah untuk memacu peningkatan produksi padi, perubahan iklim, rusaknya prasarana irigasi dan kendala lainnya. Di satu sisi kebutuhan pangan terutama beras terus meningkat akibat pertambahan penduduk dan peningkatan daya beli. Apabila Indonesia tidak mampu memenuhi kebutuhan beras masyarakatnya dari produksi dalam negeri, dan mengandalkan impor dari negara lain, maka kondisi ini akan sangat rawan bagi stabilitas nasional. Menurut Solahuddin (2009), ketergantungan terhadap beras impor merupakan cerminan dari rawannya ketahanan pangan yang dapat mengganggu ketahanan nasional. Pada kondisi tertentu, ketiadaan stok beras dapat memicu terjadinya gejolak sosial yang dapat meresahkan masyarakat dan akhirnya bisa mengganggu stabilitas nasional.

$\begin{array}{ccr}\text { Keputusan } & \text { petani } & \text { dalam } \\ \text { mengalokasikan } & \text { sumberdaya } & \text { yang }\end{array}$
dimilikinya, baik lahan, tenaga kerja, maupun dana bagi berbagai pilihan usahatani ditentukan oleh respon petani terhadap harga, kebijakan pemerintah dan faktor-faktor lainnya yang terjadi di dunia nyata. Respon petani tersebut sangat menentukan keberhasilan peningkatan produksi, karena pada akhirnya petani yang akan mengambil keputusan terhadap produksi dan jenis kegiatan usaha yang dilakukan. Menurut Ketua Divisi Ilmu Sosial International Rice Reserach Institute (IRRI), Hosain(2006), petani dan para pekerja lainnya di usaha pertanian khususnya padi akan terdorong 
untuk berusaha lebih giat ketika harga beras membaik sehingga proteksi pasar domestik akan memberikan jaminan perbaikan pada harga beras. Akibatnya,ekonomi desa akan bergerakbegitu harga komoditas di desa mengalami perbaikan. Hosain mencontohkan, usaha tani padi di China mulai kurang menarik setelah harga beras selalu rendah. Berdasarkan pada permasalahan yang telah dirumuskan, maka penelitian ini bertujuan untuk: (1) Menganalisis perkembangan penawaran padi Indonesia.

\section{METODE PENELTIAN}

Data yangdigunakandalam penelitianadalah data time series dari tahun 1981 sampai dengan tahun 2013 (kurun waktu $\quad 33 \quad$ tahun).Datatersebut meliputidataluasarealpanen,produksi

padi,hargagabah ditingkat petani,harga pupukurea,hargakomoditisubstitusi(jagung),u pah buruh tani dantren (teknologi).Datadiambil dari publikasi Badan Pusat Statistik,Kementan, IRRI dan instansi terkait lainnya.

Dalam penelitian ini analisis data yang digunakan adalah analisis statistika deskriptif dan analisis statistika inferensia (ekonometrika) dengan menggunakan uji statistik yang didasarkan pada teori ekonomi. Analisis statistika deskriptif dilakukan untuk mengetahui gambaran perkembangan penawaran padi Indonesia.

Analisis statistika inferensiadilakukan terhadap faktor-faktor yang mempengaruhi yang luas areal panen dan produktivitas padi. Analisis ini digunakan untuk menduga model-model yang digunakan serta menghitung besaran elastisitas dan berbagai macam pengujian terhadap variabel yang digunakan.

Model yang digunakan adalah model respon penawaran Nerlove (1958). Model yang dibangun merupakan persamaan tunggal yang terdiri dari dua persamaan yaitu model luas areal panen dan model produktivitas padi.

Model penawaran padi diduga secara tidak langsung dari model luas areal panen dan model produktivitas. Adapun model penawaran Nerlove diperoleh dari tiga persamaan (Anindita, 2008):

$A_{t}^{*}=a_{0}+a_{1} P_{t}^{*}+a_{2} Z_{t}+u_{t}$

$P_{t}^{*}=P_{t-1}^{*}+\beta\left(P_{t-1}-P_{t-1}^{*}\right)$

$A_{t}=A_{t-1}+\gamma\left(A_{t}^{*}-A_{t-1}\right)$

Dimana :

$A_{t}=$ luas areal aktual pada waktu t

$A_{t}^{*}=$ luas areal yang diharapkan pada

waktu $\mathrm{t}$

$P_{t}=$ harga aktual pada waktu $\mathrm{t}$

$P_{t}^{*}=$ harga yang diharapkan pada

waktu $\mathrm{t}$

$Z_{t} \quad=$ variabel lain yang mempengaruhi

luas areal, dan

$\beta=$ koefisien harapan

$\gamma \quad=$ koefisien penyesuaian

Dari persamaan (3):

$A_{t}=\gamma A_{t}^{*}+(1-\gamma) A_{t-1}$

Substitusikan persamaan (1) ke persamaan (4):

$$
\begin{aligned}
A_{t}= & \gamma\left[a_{0}+a_{1} P_{t}^{*}+a_{2} Z_{t}+u_{t}\right]+ \\
& (1-\gamma) A_{t-1} \\
A_{t}= & \gamma a_{0}+\gamma a_{1} P_{t}^{*}+\gamma a_{2} Z_{t}+\gamma u_{t}+ \\
& (1-\gamma) A_{t-1}
\end{aligned}
$$

Dari persamaan (2):

$P_{t}^{*}=\beta P_{t-1}+(1-\beta) P_{t-1}^{*}$

Substitusikan persamaan (6) ke persamaan (5):

$$
\begin{gathered}
A_{t}=\gamma a_{0}+\gamma a_{1}\left[\beta P_{t-1}+(1-\beta) P_{t-1}^{*}\right] \\
+\quad \gamma a_{2} Z_{t}+\gamma u_{t}+(1 \\
-\gamma) A_{t-1} \\
A_{t}=\gamma a_{0}+\gamma a_{1} \beta P_{t-1}+\gamma a_{1}(1-\beta) P_{t-1}^{*} \\
+\gamma a_{2} Z_{t}+\gamma u_{t}+(1-\gamma) A_{t-1}
\end{gathered}
$$

Persamaan (5) di-lag-kan satu periode:

$$
A_{t-1}=\gamma a_{0}+\gamma a_{1} P_{t-1}^{*}+\gamma a_{2} Z_{t-1}+
$$$$
\gamma u_{t-1}+(1-\gamma) A_{t-2}(8)
$$ 
Mengalikan persamaan (8) dengan (1- $\beta)$ :

$$
\begin{gathered}
A_{t-1}(1-\beta)=\gamma a_{0}(1-\beta) \\
+\gamma a_{1}(1-\beta) P_{t-1}^{*} \\
+\gamma a_{2}(1-\beta) Z_{t-1} \\
+\gamma(1-\beta) u_{t-1} \\
+(1-\beta)(1-\gamma) A_{t-2}
\end{gathered}
$$

(9)

Mengurangi persamaan (7) dengan persamaan (9):

$$
\begin{gathered}
A_{t}=\gamma a_{0}+\gamma a_{1} \beta P_{t-1}+\gamma a_{1}(1-\beta) P_{t-1}^{*}+ \\
\gamma a_{2} Z_{t}+\gamma u_{t}+(1-\gamma) A_{t-1} \\
-\gamma a_{0}+\gamma a_{0} \beta-\gamma a_{1}(1-\beta) P_{t-1}^{*}- \\
\gamma a_{2}(1-\beta) Z_{t-1}-\gamma(1-\beta) u_{t-1}- \\
\quad(1-\beta)(1-\gamma) A_{t-2}+(1-
\end{gathered}
$$

$\beta) A_{t-2}(10)$

Menyederhanakan persamaan (10):

$$
\begin{aligned}
A_{t}=\gamma a_{0} \beta+\gamma & a_{1} \beta P_{t-1} \\
& +[(1-\beta)+(1 \\
& -\gamma)] A_{t-1} \\
& +\left[\gamma u_{t}-\gamma(1\right. \\
& \left.-\beta) u_{t-1}\right] \\
& +\left[\gamma a_{2} Z_{t}\right. \\
& \left.-\gamma a_{2}(1-\beta) Z_{t-1}\right] \\
-(1-\gamma)(1-\beta) & A_{t-2}
\end{aligned}
$$

Menggunakan reduced form sehingga:

$A_{t}=b_{0}+b_{1} P_{t-1}+b_{2} A_{t-1}+b_{3} A_{t-2}+$

$b_{4} Z_{t}+\quad b_{5} Z_{t-1}+v_{t}$

Dimana:

$$
\begin{aligned}
& b_{0}=a_{0} \beta \gamma ; b_{1}=a_{1} \beta \gamma ; \\
& b_{2}=(1-\beta)(1-\gamma) ; \\
& b_{3}=-(1-\beta)(1-\gamma) ; \\
& b_{4}=\gamma a_{2} ; b_{5}=-\gamma a_{2}(1-\beta) \\
& v_{t}=\gamma\left(u_{t}-(1-\beta) u_{t-1}\right)
\end{aligned}
$$

\section{Aplikasi :}

1. ModelLuas Areal Panen Padi Indonesia:

$$
\begin{gathered}
A_{t}=b_{0}+b_{11} H G_{t-1}+b_{12} A_{t-1}+b_{13} A_{t-2} \\
+b_{14} H J_{t}+b_{15} H J_{t-1} \\
+b_{16} Q P_{t} \\
+b_{17} Q P_{t-1}+\varepsilon_{1}
\end{gathered}
$$

Dimana:

$A_{t} \quad=$ Luas areal panen padi pada waktu t,

$H G_{t-1}=$ Harga gabah/padi satu tahunsebelumnya,

$A_{t-1}=$ Luas areal panen satu tahun sebelumnya,

$A_{t-2}=$ Luas areal panen dua tahun sebelumnya,

$H J_{t} \quad=$ Harga komoditas pesaing

(Jagung) pada waktu t,

$H J_{t-1}=$ Harga komoditas pesaing

(Jagung) satu tahun sebelumnya,

$Q P_{t}=$ Produksi pada waktu $\mathrm{t}$,

$Q P_{t-1}=$ Produksi satu tahun

sebelumnya,

$b_{i} \quad=$ koefisien regresi

$\varepsilon_{1} \quad=$ Nilai residu

Elastisitas jangka pendek $\left(E_{\mathrm{SR}}\right)$ dari model luas areal panen (Leaver, 2004), yaitu:

$$
E_{11(A P)}=E_{11(S R)}=b_{11}
$$

Sedangkan elastisitas jangka panjang ( $\left.\mathrm{E}_{\mathrm{LR}}\right)$ dari model luas areal panen(Braulke, 1982):

$$
E_{11(A P)}=E_{11(L R)}=\frac{b_{11}}{1-b_{12}-b_{13}}
$$

2. ModelProduktivitas Padi Indonesia:

$$
\begin{aligned}
& Y_{t}=b_{0}+b_{21} H G_{t-1}+b_{22} Y_{t-1}+b_{23} Y_{t-2} \\
& +b_{24} A_{t}+b_{25} A_{t-1}+b_{26} H P U_{t}+ \\
& b_{27} H P U_{t-1}+b_{28} T_{t}+b_{29} T_{t-1}+b_{210} U T_{t}+ \\
& b_{211} U T_{t-1}+\varepsilon_{2}(14)
\end{aligned}
$$

Dimana:

$Y_{t} \quad=$ Produktivitas padi pada

waktu t,

$H G_{t-1} \quad=$ Harga padi tahun

sebelumnya,

$Y_{t-1} \quad=$ produktivitas padi satu tahun sebelumnya,

$Y_{t-2} \quad=$ produktivitas padi dua tahun sebelumnya,

$A_{t} \quad=$ Luas areal panen padi pada waktu t,

$A_{t-1} \quad=$ Luas areal panen satu tahun sebelumnya,

$H P U_{t} \quad=$ Harga pupuk urea pada

waktu t,

$H P U_{t-1}=$ harga pupuk urea satu tahun

sebelumnya, 
$T_{t} \quad=$ tren (mewakili teknologi)

pada waktu $\mathrm{t}$,

$T_{t-1} \quad=$ tren satu tahun sebelumnya,

$U T_{t} \quad=$ upahburuh tani pada waktu

$\mathrm{t}$,

$U T_{t-1}=$ upah buruh tani satu tahun sebelumnya.

$\varepsilon_{2} \quad=$ Nilai residu

Dengan cara yang sama, elastisitas jangka pendek $\left(E_{S R}\right)$ dan jangka panjang $\left(\mathrm{E}_{\mathrm{LR}}\right)$ produktivitas padi dihitung dari persamaan (14) dengan rumus sebagai berikut (Leaver, 2004):

$$
E_{21(Y P)}=E_{S R}=b_{21}
$$

Sedangkan elastisitas jangka panjang (Braulke, 1982):

$E_{21(Y P)}=E_{21(L R)}=\frac{b_{21}}{1-b_{22}-b_{23}}$

Berdasarkan respon areal dan respon produktivitas, maka elastisitas (respon) penawaran dapat diduga dengan persamaan berikut:

$$
E_{(Q)}=E_{(A P)}+E_{(Y P)}
$$

\section{HASIL DAN PEMBAHASAN}

\section{Perkembangan Penawaran Padi Indonesia}

Selama kurun waktu 1981-2013 (33 tahun), perkembangan penawaran padi Indonesia mengalami pertumbuhan yang cukup baik, meskipun dari tahun ke tahun mengalami fluktuasi. Hal ini dapat dilihat dari rata-rata pertumbuhan produksi padi sebesar $2,51 \%$ per tahun, yang mana pertumbuhan ini karena adanya pertumbuhan luas areal panen dan produktivitas padi, dengan masing-masing sebesar $1,26 \%$ dan $1,24 \%$ per tahun.

Pertumbuhan ini tidak lepas dari peran pemerintah dalam usaha meningkatkan produksi padi di Indonesia, sehingga Indonesia mampu berswasembada beras untuk pertama kalinya pada tahun 1984 dan mendapat pengakuan dari dunia Internasional melalui FAO.
Swasembada beras ini dapat dicapai karena pemerintah terus menyempurnakan pelaksanaan BIMAS (Bimbingan Massal), yaitu melalui program Intensifikasi Umum (INMUM) dan Intensifikasi Khusus (INSUS). Inmum merupakan program intensifikasi yang dilakukan petani perorangan dengan tidak menjalin usahatani berkelompok, sedangkan Insus merupakan intensifikasi yang dilakukan dengan ikatan kerjasama kelompok tani pada suatu hamparan usahatani guna memanfaatkan potensi lahan, teknologi, daya dan dana secara optimal untuk menerapkan anjuran Sapta Usahatani secara lengkap.

\section{Hasil Estimasi Model Luas Areal Panen}

Berdasarkan hasil regresi persamaan respon luas areal panen padi diketahhui bahwa nilai koefisien determinasi $\left(\mathrm{R}^{2}\right)$ sebesar 0,99. Hal ini dapat diartikan bahwa variasi variabel terikat dapat dijelaskan sebesar 99\% oleh semua variabel bebas, sedangkan sisanya sebesar $1 \%$ dijelaskan variabel bebas diluar model. Sedangkan dari hasil pengujian $\mathrm{F}$ didapatkan nilai probabilitas $\mathrm{F}$ sebesar 0,0000 yang berarti bahwa secara keseluruhan variabel bebas yang menyusun model berpengaruh nyata terhadap variabel terikatnya yang ditunjukkan dengan nilai Prob $\mathrm{F}$ lebih kecil dari tingkat signifikasi $(\alpha=0,10)$. Intersep persamaan ini sebesar 1,905426, yang berarti bahwa pada saat seluruh variabel bebas dalam persamaan sama dengan nol, maka luas areal panen padi sebesar 1,905426. Dalam persamaan ini variabel bebas yang berpengaruh nyata terhadap persamaan, yakni variabel harga riil gabah satu tahun sebelumnya, luas areal panen satu dan dua tahun sebelumnya, harga riil jagung satu tahun sebelumnya, dan produksi padi tahun ini dan satu tahun sebelumnya. Sedangkan variabel bebas yang tidak berpengaruh nyata, yakni variabel harga jagung pada tahun ini. 


\section{Hasil Estimasi Model Produktivitas Padi}

Berdasarkan hasil regresi persamaan produktivitas padi diketahui bahwa nikai koefisien determinasi $\left(\mathrm{R}^{2}\right)$ sebesar 0,98 . Hal ini dapat diartikan bahwa variasi variabel terikat dapat dijelaskan sebesar $98 \%$ oleh semua variabel bebas, sedangkan sisanya sebesar $2 \%$ dijelaskan variabel bebas diluar model. Sedangkan dari hasil pengujian $\mathrm{F}$ didapatkan nilai probabilitas $\mathrm{F}$ sebesar 0,0000 yang berarti bahwa secara keseluruhan variabel bebas yang menyusun model berpengaruh nyata terhadap variabel terikatnya yang ditunjukkan dengan nilai Prob $\mathrm{F}$ lebih kecil dari tingkat signifikasi $(\alpha=0,10)$. Intersep persamaan ini sebesar 1,718612 , yang berarti bahwa pada saat seluruh variabel bebas dalam persamaan sama dengan nol, maka luas areal panen padi sebesar 1,718612. Dalam persamaan ini variabel bebas yang berpengaruh nyata terhadap produktivitas, yakni variabel produktivitas satu tahun sebelumnya,tren (teknologi) tahun ini dan satu tahun sebelumnya, sertaUpah Buruh Tani satu tahun sebelumnya. Sedangkan variabel yang tidak berpengaruh nyata, yaitu harga gabah satu tahun sebelumnya, produktivitas dua tahun sebelumnya, luas areal panen satu tahun sebelumnya dan tahun ini, harga pupuk urea satu tahun sebelumnya dan tahun ini, serta upah buruh tani tahun ini.

\section{Elastisitas Penawaran}

Berdasarkan perhitungan elastisitas, diketahui bahwa elastisitas luas areal panen atas perubahan harga gabah dalam jangka pendek dan jangka panjang masing-masing sebesar 0,053 dan 0,090. Nilai elastisitas ini sama-sama jatuh pada kisaran inelastic, yang menyiratkan bahwa luas areal panen relatif tidak responsif terhadap perubahan harga. Sedangkan elastisitas produktivitas padi dalam jangka pendek dan jangka panjang masing-masing sebesar 0,034 dan 0,068.

Berdasarkan nilai elastisitas luas areal panen dan produktivitas padi, maka nilai elastisitas penawaran padi Indonesia dalam jangka pendek dan jangka panjang masingmasing sebesar 0,087 dan 0,158. Secara spesifik, peningkatan 1 persen pada harga gabah akan meningkatkan output padi sebesar 0,087 persen dalam jangka pendek dan sebesar 0,158 persen dalam jangka panjang.

Dalam rangka peningkatan produksi beras, maka kebijakan yang tepat adalah kebijakan ekstensifikasi lahan dan mengingat kompetisi penggunaan lahan di Pulau Jawa semakin tinggi akibat pertumbuhan penduduk dan pembangunan ekonomi, maka kebijakan ini sangat tepat bila dilaksanakan di luar Pulau Jawa.

\section{Elastisitas Harga Jagung Terhadap Luas Areal Panen Padi}

Elastisitas harga jagung terhadap luas areal panen padi dalam jangka pendek sebesar -0,065 dan jangka panjang sebesar 0,110 . Hal ini memiliki arti bahwa jika harga jagung naik sebesar $1 \%$ maka dalam jangka pendek akan menurunkan luas areal panen padi sebesar $0,065 \%$ dan dalam jangka panjang dapat menurunkan luas areal panen padi sebesar $0,110 \%$. Dan sebaliknya jika harga jagung turun sebesar $1 \%$, maka dalam jangka pendek akan menaikkan luas areal panen padi sebesar $0,065 \%$ dan dalam jangka panjang sebesar $0,110 \%$. Nilai elastisitas harga jagung terhadap luas areal panen padi berada dalam kisaran inelastis, namun demikian nilainya lebih besar jika dibandingkan dengan nilai elastisitas harga gabah. Hal ini dapat diartikan bahwa respon petani terhadap harga jagung lebih responsif terhadap harga gabah baik dalam jangka pendek maupun dalam jangka panjang.

\section{KESIMPULAN DAN SARAN}

\section{Kesimpulan}

1. Selama kurun waktu 1981-2013 (33 tahun), penawaran padi Indonesia memilikikecenderungan pening-katan tiap tahunnya. Dimana rata-rata pertumbuhan 
produksi padi sebesar 2,51 persen per tahun. Pertumbuhan ini karena adanya pertumbuhan luas areal panen dan produktivitas padi, dengan masing-masing sebesar 1,26 dan 1,24 persen per tahun.

2. Luas areal panen padi dipengaruhi secara nyata oleh variabel harga riil gabah satu tahun sebelumnya, luas areal panen satu dan dua tahun sebelumnya, harga riil jagung satu tahun sebelumnya, produksi padi tahun ini dan satu tahun sebelumnya. Sedangkan variabel bebas yang tidak berpengaruh nyata, yakni variabel harga jagung pada tahun ini.

3. Produktivitas padi dipengaruhi secara nyata olehvariabel produkti-vitas satu tahun sebelum-nya, tren (teknologi) tahun ini dan satu tahun sebelumnya, serta Upah Buruh Tani satu tahun sebelumnya. Sedangkan variabel yang tidak berpengaruh nyata, yaitu harga gabah satu tahun sebelumnya, produktivitas dua tahun sebelumnya, luas areal panen satu tahun sebelumnya dan tahun ini, harga pupuk urea satu tahun sebelumnya dan tahun ini, serta upah buruh tani tahun ini.

4. Elastisitas penawaran padi Indonesia dalam jangka pendek sebesar 0,087 dan elastisitas jangka panjang sebesar 0,158 . Hal inimenunjukkan bahwa petani padi respon terhadap perubahan harga. Nilai elastisitas ini berada pada kisaran inelastis, artinya presentase perubahan penawaran lebih kecil daripada harganya yaitu sebesar 0,087 persen dalam jangka pendek dan 0,158 persen dalam jangka panjang sebagai akibat perubahan 1 persen harga gabah.

\section{DAFTAR PUSTAKA}

Anindita, R. 2008. Pendekatan Ekonomi untuk Analisis Harga. Jakarta: Kencana Prenada Media Group.

Amang, B dan Sawit, M.H. 1999. Kebijakan Beras dan Pangan Nasional Pelajaran dari Orde Baru dan Era Reformasi. Jakarta: IPB Press.

Ariani, M. 2010. Diversifikasi Konsumsi Pangan Pokok Mendukung Swasembada Beras. Prosiding Pekan Serealia Nasional. http://balitsereal.litbang.pertanian.go.i d

Bappenas. 2013. Studi Pendahuluan Rencana Pembangunan Jangka MenengahNasional (RPJMN) Bidang Pangan dan Pertanian 20152019.Jakarta

Braulke, M. 1982. A Note On the Nerlove Model Of Argicultural Supply Response. International Economic Review 23(1):241-246.

Gujarati, Damodar N. 2003. Basic Econometric, Fourth Edition. United States Military Academy, West Point. Mc Graw Hill Companies. New York.

Hanani, Nuhfil. Diversifikasi Konsumsi Pangan. $\quad$ http:// nuhfil.lecture.ub.ac.id/files/.../8diversif ikasi-konsumsi-pangan-8.pdf.

Leaver, R. 2004. Measuring the Supply Response Function of Tobacco in Zimbabwe. Agrekon, Vol 43, No 1.

Nerlove, M. 1958. The Dynamic Of Supply: Estimation of Farmers Response to Price. The John Hopkins Press, Baltimore, United State of America.

Solahuddin, S. 2009. Pertanian : Harapan Masa Depan Bangsa. IPB Press, Bogor.

Suryana, A., J. Winoto, B. Krisnamurthi, dkk. 2001. Bunga Rampai Ekonomi Beras. Lembaga Penyelidikan Ekonomi dan Masyarakat Fakultas Ekonomi, Universitas Indonesia, Badan Bimas Ketahanan Pangan Departemen Pertanian dan Badan Perencanaan Pembangunan Nasional, Jakarta. 